\title{
On-Line Water Consumption Monitoring as a Tool for Optimal Management of Water Distribution Network ${ }^{\dagger}$
}

\author{
Joanna Gwoździej-Mazur ${ }^{1, *}$, Dariusz Andraka ${ }^{1}\left(\mathbb{D}\right.$, Bartosz Kaźmierczak $^{2}\left(\mathbb{D}\right.$ and Wojciech Kruszyński ${ }^{1}(\mathbb{D}$ \\ 1 Faculty of Civil Engineering and Environmental Sciences, Bialystok University of Technology, ul. Wiejska 45E, \\ 15-351 Bialystok, Poland; d.andraka@pb.edu.pl (D.A.); w.kruszynski@pb.edu.pl (W.K.) \\ 2 Faculty of Environmental Engineering, Wrocław University of Science and Technology, \\ 50-377 Wrocław, Poland; bartosz.kazmierczak@pwr.edu.pl \\ * Correspondence: j.mazur@pb.edu.pl; Tel.: +48-793-707-470 \\ + Presented at the Innovations-Sustainability-Modernity-Openness Conference (ISMO'21), Bialystok, Poland, \\ 14 May 2021.
}

check for

updates

Citation: Gwoździej-Mazur, J.; Andraka, D.; Kaźmierczak, B.; Kruszyński, W. On-Line Water Consumption Monitoring as a Tool for Optimal Management of Water Distribution Network. Environ. Sci. Proc. 2021, 9, 26. https://doi.org/ 10.3390 /environsciproc2021009026

Academic Editors: Dorota Anna Krawczyk, Iwona Skoczko, Antonio Rodero Serrano and Ewa Szatyłowicz

Published: 9 November 2021

Publisher's Note: MDPI stays neutral with regard to jurisdictional claims in published maps and institutional affiliations.

Copyright: (C) 2021 by the authors. Licensee MDPI, Basel, Switzerland. This article is an open access article distributed under the terms and conditions of the Creative Commons Attribution (CC BY) license (https:/ / creativecommons.org/licenses/by/ $4.0 /)$.

\begin{abstract}
Monitoring and computer modeling of water networks is an effective tool supporting water management in the city. The aim of this paper is to present the results of measurement campaigns carried out in Polanica-Zdrój, preceding the construction, calibration and validation of the hydrodynamic model of the water supply network. The obtained results showed that the changed conditions of the functioning of the local community during a pandemic also significantly affect the way water is used. Daily distribution of water consumption by residents of multi-family housing has been significantly "flattened" due to remote work and extended time at home. This confirms the necessity to conduct on-line measurements in order to calibrate the model reliably and effectively use the results of computer simulations.
\end{abstract}

Keywords: on-line monitoring; water; consumption; distribution; modeling; management

\section{Introduction}

One of the most important elements that affect the strategy of a water company is managing the water demand in the city. The activities that are undertaken in this area include metering, water accounting, pricing policy, water loss control and education [1]. Hydrodynamic modeling of water supply and sewage networks can be an important tool supporting sustainable water management in the city. On-line measurements and computer simulations make it possible to quickly find the optimal variant of solving the problem with the water supply network and to enable an economically effective decisions regarding their modernization, without the need to make physical changes to the system. The aim of the work is to present the results of measurement campaigns carried out in Polanica-Zdrój, preceding the calibration and validation of the hydrodynamic model of the water supply network, which will be one of the main elements of the water management system in the city.

\section{Materials and Methods}

The water supply network in Polanica-Zdrój consists of $14.3 \mathrm{~km}$ of transmission and feeder mains (DN200-350 mm), $64.3 \mathrm{~km}$ of distribution mains (DN80-160 mm) and approx. 6.2 thousand service connections. The system is supplied from 5 intakes (underground and drainage water) cooperating with 6 elevated ground storage reservoirs. Due to the significant differences in terrain elevation, 19 pressure regulators were installed on the network to adjust the pressure in the system. Currently, a computer model of the water supply network is being developed; therefore, a metering campaign was carried out, including measurements of pressure, flows and water demand. The measurement campaign conducted so far has covered 20 pressure measurement points on the water supply network 
(sensors mounted on fire hydrants) and 40 points with recorders installed on water meters for various groups of consumers. All measuring devices were equipped with GSM data transmission modules. The analyzed results of flow measurements were obtained in March 2021, so they reflect the network operating conditions in the COVID-19 pandemic during a partial lockdown period.

\section{Results and Discussion}

Flows in the water supply network are subject to cyclical daily and hourly fluctuations (Figure 1), which is an obvious result of the changing demand for water by consumers. Therefore, the key element determining the hydraulic conditions in the water supply network is to determine the characteristics of water consumption for various groups of users (multi-family, single-family housing, commercial, industry, etc.).

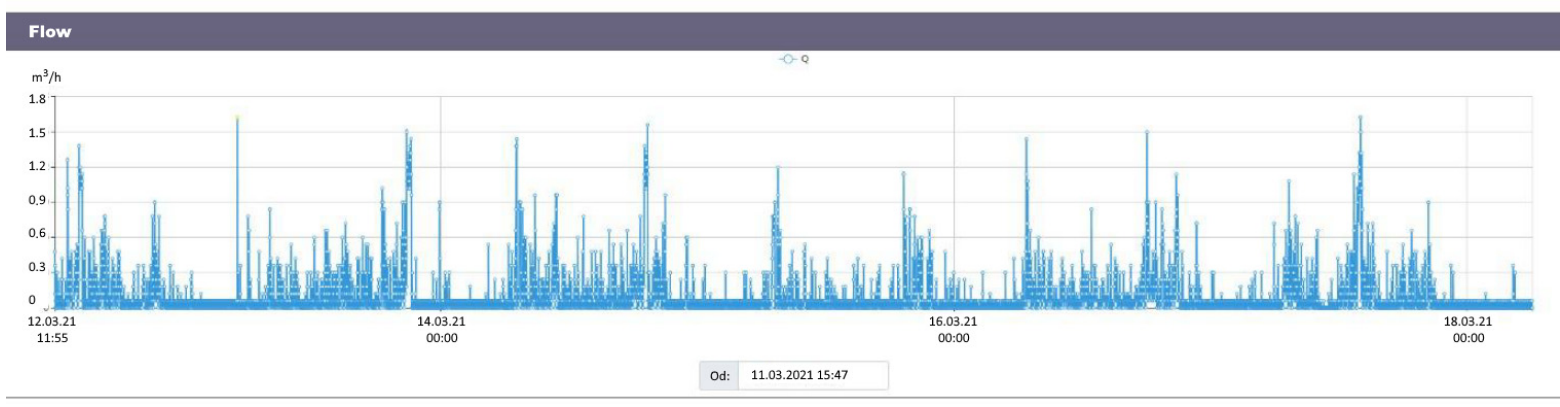

Figure 1. Variation of flow in the selected distribution main.

The basic parameter characterizing the variability of water consumption is the hourly demand factor (HDF), which determines the ratio of the hourly amount of water used to the average hourly consumption for a given consumer. The maximum value of this factor (peak hour, $\mathrm{PH}$ ) is one of the most important parameters used in the design of water supply infrastructure. Figure 2a shows the variability of the daily water consumption for a group of multi-family housing (MF) recipients, while Figure $2 \mathrm{~b}$ shows a comparison of the HDF determined within presented study with the literature data $[2,3]$.
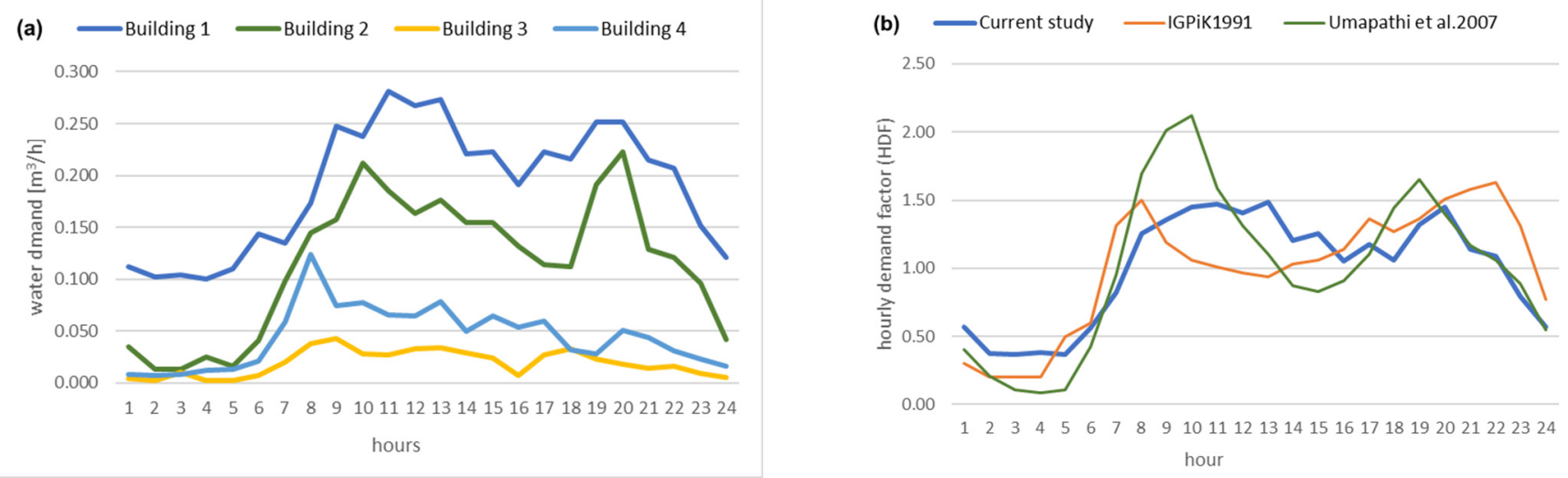

Figure 2. (a) Variability of water consumption in selected MF buildings; (b) comparison of hourly demand factors (HDF) for the studied area against other studies $[2,3]$.

From the analysis of the hourly variability of water consumption, significant differences between the studied objects and the data available in the literature can be observed. These differences are mainly due to changes in the lifestyle of residents caused by the pandemic and lockdown. The hourly water demand profile in the tested MF facilities has clearly flattened, the highest hourly water consumption falls in the morning hours and is 
extended in time, another short-time increase in consumption takes place in the evening hours. This is due to the fact that residents are at home most of the day (remote work and education), and therefore water consumption is more even throughout the day.

The obtained results confirm that in order to accurately characterize the parameters of the water supply network in terms of creating and calibrating, and then validating the computer model of the network, it is necessary to test the network in real conditions, because the use of literature data may lead to incorrect assignment of model parameters and erroneous simulation results. As a consequence, the risk of making wrong decisions in the management of the system increases.

Author Contributions: J.G.-M. and B.K. conceived and designed the experiments, J.G.-M., B.K. and D.A. performed the experiments; J.G.-M., W.K. and D.A. analyzed the data; W.K. and D.A. wrote the paper. All authors have read and agreed to the published version of the manuscript.

Institutional Review Board Statement: Not applicable.

Informed Consent Statement: Not applicable.

Data Availability Statement: Data is contained within the article.

Acknowledgments: This research is being conducted as part of the grant no. POIR.01.01.01-000349/19 "Protection of natural water resources in Polanica Zdrój through intelligent water and sewage management" financed by Polish National Centre for Research and Development.

Conflicts of Interest: The authors declare no conflict of interest.

\section{References}

1. Boyle, T.; Giurco, D.; Mukheibir, P.; Liu, A.; Moy, C.; White, S.; Stewart, R. Intelligent Metering for Urban Water: A Review. Water 2013, 5, 1052-1081. [CrossRef]

2. Umapathi, S.; Chong, M.N.; Sharma, A.K. Assessment of diurnal water demand patterns to determine supply reliability of plumbed rainwater tanks in South East Queensland. In Proceedings of the 7th International Conference on Water Sensitive Urban Design, Melbourne, Australia, 2012. Available online: https://www.researchgate.net/publication/272820571_Assessment_of_ diurnal_water_demand_patterns_to_determine_supply_reliability_of_plumbed_rainwater_tanks_in_South_East_Queensland (accessed on 28 March 2021).

3. Wytyczne do Programowania Zapotrzebowania Wody i Ilości Ścieków w Miejskich Jednostkach Osadniczych; Instytut Gospodarki Przestrzennej i Komunalnej: Warszawa, Poland, 1991. 